\title{
Conceptualizing the Socio-Ecological Resilience of the Chaya Rice Terraces, a Socio-Ecological Production Landscape in Mayoyao, Ifugao, Luzon Island, Philippines
}

\author{
Jhoanna O. Santiago \\ (corresponding author)
}

School of Environmental Science and Management, University of the Philippines Los Baños, College Laguna josantiago1@up.edu.ph

\author{
Inocencio E. Buot, Jr. \\ School of Environmental Science and Management, University of \\ the Philippines Los Baños, College Laguna \\ Institute of Biological Sciences, College of Arts and Sciences, \\ University of the Philippines Los Baños, College Laguna \\ Faculty of Management and Development Studies, University of \\ the Philippines Los Baños, College Laguna
}

Publication Information:

Received 29 March 2018, Accepted 25 April 2018, Available online 30 June 2018 doi: 10.21463/jmic.2018.07.1.07

\section{Abstract}

Socio-ecological Production Landscape (SEPL) especially in an island landscape plays a major role in providing ecosystem services and biodiversity conservation. Despite the significance of SEPL, conservation is still a major challenge. The Chaya socio-ecological production landscape (CSEPL) of Luzon Island is in peril due to various reasons. This study is aimed to conceptualize the resilience of CSEPL on the perspective of the local community. The study employed a qualitative research design. Data were collected using focus groups discussion (FGD) and were analyzed using thematic analysis. As the result of conducting this research, socio-ecological resilience of the Chaya Rice Terraces as a Socio-Ecological Production Landscape is conceptualized by the people as the ability of the traditional landscape to provide ecosystem services like food and aesthetics. The local people believed that this resilience can be maintained by enhancing the five resilience building strategies namely: 1) farming practice, 2) cultural tradition, 3) social network, 4) financial capital and 5) natural resources. The findings of this study can serve as guide for policy formulators in making positive interventions to address the issues in CSEPL.

\section{Keywords}

determinants of resilience, conceptualization, socio-ecological production landscape, Luzon Island 


\section{Introduction}

Resilience is a complex construct that may be defined differently in the context of individuals, families, organizations, societies and cultures (Southwick et al., 2014). In the context of socio-ecological production landscape (SEPL), resilience refers to "the ability of the SEPL to absorb or recover in terms of both ecosystem processes and socio-economic activity from various pressures and disturbances without lasting damage" (UNU-IAS et al., 2014). In relation to agricultural system in an island landscape, a system is resilient if it can maintain productivity and can withstand stress or external shocks in an isolated state. This means that it can provide vital service such as food production despite the presence of drought or reduction in rainfall (Di Falco and Chavas, 2008). To further visualize what resilience is, Araral (2013) described the Ifugao Rice Terraces (IRT) in the northern Philippines as a resilient socio-ecological system. IRT has been continuously playing an important role to the local community by providing ecosystem services such as provision of food and water, regulation of floods, nutrient cycling, and spiritual benefits (Ngidlo, 2013b). However, the resilience of IRT is being challenged by contemporary issues this time (SITMo, 2008; Araral, 2013; Ngidlo, 2011). The rice terraces are now threatened by climate impacts and socio-cultural changes. In situations like these, assessing the resilience helps to identify vulnerabilities in social-ecological systems so that action can be taken to create more sustainable future for people and the land (Berkes et al., 2003). In resilience assessments, specifying what system state is being considered (resilience of what), what perturbations are of interest (resilience to what) and what determinants of resilience are needed to be measured are crucial (Carpenter et al., 2001; Khalili et al., 2015). These three are the central elements of this study. This study selected the rice terraces of Chaya, a village in Mayoyao, Ifugao because to date, there is limited information on the resilience of rice terraces located in the remote areas. Resilience studies are mostly concentrated in the well-known rice terraces of Banaue, Ifugao (Castonguay et al., 2016). To fill this gap, a study was conducted using participatory approach where the indigenous people of Chaya conceptualized the socio-ecological resilience elements of their SEPL. The study addressed two primary research questions. Firstly, what are the determinants of socio-ecological resilience? Secondly, what are the major challenges that have recently been confronted within the SEPL?

\section{Study Area}

Barangay Chaya is one of the 27 barangays (village) of the municipality of Mayoyao, Ifugao (Fig. 1). The barangay has a total land area of 1,314 ha or $3.92 \%$ of the total land area of the municipality. Barangay Chaya has a total population of 870 (NSO Census of Population, 2010). The village people speak the Henanga dialect, considered the most dominant. Chaya is the home of Chaya Rice Terraces, one of the eight rice terraces of Central Mayoyao Rice Terraces inscribed as UNESCO World Heritage Site in Mayoyao, Ifugao.

Barangay Chaya's climate is classified as tropical. Rainfall is significant in most months of the year, and the short dry season has little effect. The Northeast monsoon locally known as "amihan" and the Pacific Trade winds influence the climate of the village. Heaviest rains occur during the months of July to November with an average annual rainfall of $1,651.4 \mathrm{~mm}$. Precipitation is lowest in February with an average of $23 \mathrm{~mm}$. Most of the precipitation falls in October, averaging $247.7 \mathrm{~mm}$. Generally, the climate is cool with annual average temperature ranging from $16^{\circ} \mathrm{C}$ to $20^{\circ} \mathrm{C}$. It is 
relatively dry from March to May and generally wet for the rest of the years. The coolest months are November, December and January while the hottest month is April (Chaya Mayoyao Project Investment Plan (CMPIP), 2011).

Barangay Chaya was selected as the study area for it has been considered the most resilient SEPL among Central Mayoyao Rice Terraces and can be a model of adapted agricultural system. Figure 2 shows Barangay Chaya composing of the village (pfuglay), rice terraces (pajaw), water bodies (gwang-gwang), swidden fields (ponhapfalan) and forest (pinuchu) making up the Chaya Socio-Ecological Production Landscape (CSEPL).

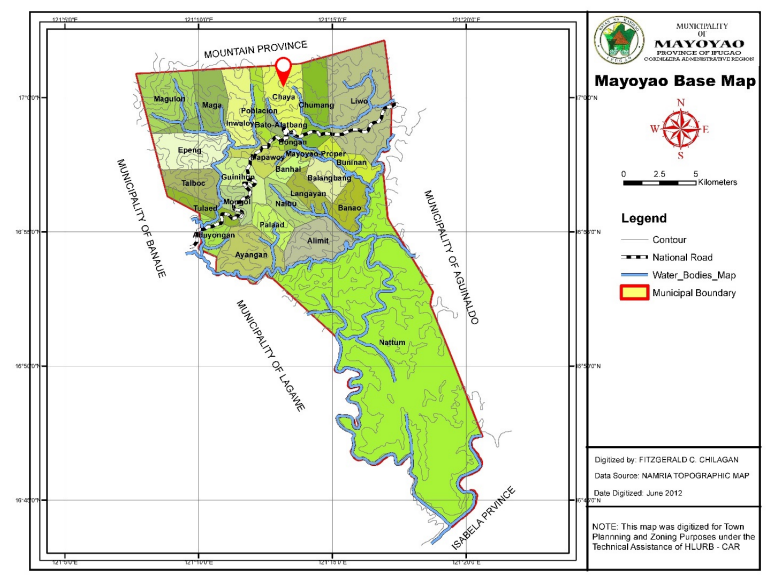

Fig 1. The Mayoyao, Ifugao Base Map indicating the location of Barangay Chaya.

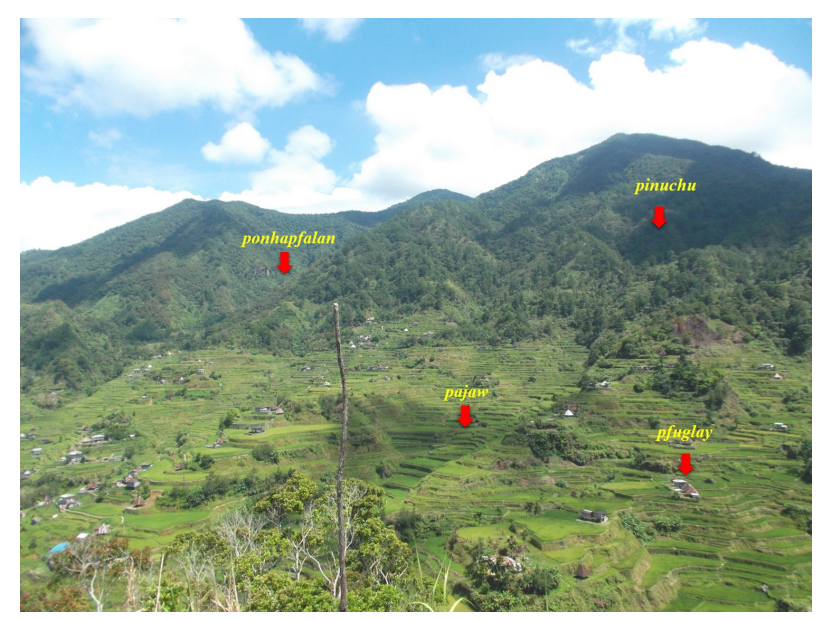

Fig 2. The components of Chaya Socio-Ecological Production Landscape (CSEPL). The gwang-gwang is not visible in the photo. 


\section{Methods}

This study employed a qualitative research design. In total, six focus group discussions (FGDs) consisting of between four to 7 participants ( $n=31$ ) were conducted. The 31 participants were from the following sectors namely: 1) Municipal local government unit, 2) Barangay local government unit of Chaya, 3) Farmers' Group, 4) Youth sector and 5) Organizations composed of members from People's organization, non-government organizations and religious organizations.

Before the commencement of each FGD, participants were asked to fill out questionnaire concerning basic demographic information. These include age, gender, number of years living in Mayoyao and occupation. In addition, written consent was obtained from all individual participants. Confidentiality of information was explained and agreed to by all participants. A uniform set of focus group guideline was used for all sessions. Instead of discussing resilience directly, participants were asked on how they persist and adapt to risks and stress factors. Each focus group lasted between 30 and $120 \mathrm{~min}$, generating $8 \mathrm{~h}$ of recordings. The interviews were audio-recorded, and the entire recordings were transcribed verbatim using Inqscribe (trial version). The transcripts were entered to QSR Nvivo 10 (trial version) software and thematically analyzed following the guidelines of Braun and Clarke (2006).

Coding followed a hybrid approach of deductive and inductive method (Fereday and Muir-Cochrane, 2006). For the deductive method of coding, Schoon and Cox (2012) typology of disturbances were used to distinguish the different disturbances where CSEPL is exposed to. Meanwhile, the general inductive approach (Thomas, 2006) for qualitative analysis was used for data-driven coding. Themes were identified at semantic and latent level using the combination of scrutiny techniques including, but not limited to, repetitions, theory-related material, similarities and differences, relationship between codes and indigenous typologies (Ryan and Bernard, 2003). Themes were categorized using the two dimensions of socio-ecological production landscape namely: socio-cultural and ecological dimension (UNU-IAS et al., 2014).

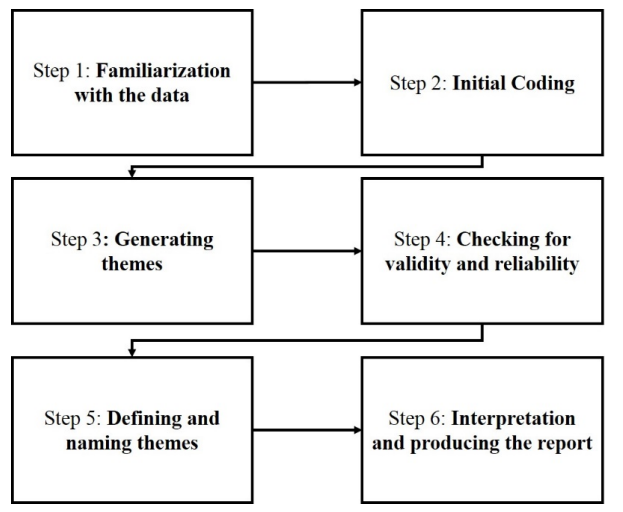

Fig 3. 3 Steps in conducting thematic analysis (Braun and Clarke, 2006). 


\section{Results}

The following sections comprised the themes generated from thematic analysis, these are divided into two sections which answered the research questions: 1) what are the determinants of socio-ecological resilience? and 2) what are the major challenges that have recently been confronted within Chaya Socio-Ecological Production Landscape (CSEPL)?

For the demographic characteristics of participants, Table 1 shows the participants' age and their number of years living in Mayoyao. In terms of the distribution by gender, there are more males (55\%) than females (45\%). The median age of the respondents is 40 years old. The youngest age interviewed is 12 years old while the oldest is 67 years old. The median number of years living in Mayoyao is 40 .

Table 1. Background characteristics of focus group participants.

\begin{tabular}{|c|c|c|c|}
\hline Background characteristics & Female $(N=14)$ & Male $(N=17)$ & Total $(N=31)$ \\
\hline \multicolumn{4}{|l|}{ Age (years) } \\
\hline $10-18$ & $2(14.29)$ & $2(11.76)$ & $4(12.90)$ \\
\hline 19-27 & $2(14.29)$ & $2(11.76)$ & $4(12.90)$ \\
\hline 28-36 & $2(14.29)$ & $1(5.88)$ & $3(9.68)$ \\
\hline $37-45$ & $3(21.43)$ & $4(23.53)$ & $7(22.58)$ \\
\hline $46-54$ & $4(28.57)$ & $3(17.65)$ & $7(22.58)$ \\
\hline $55-63$ & - & $3(17.65)$ & $3(9.68)$ \\
\hline 64 and above & $1(7.14)$ & $2(11.76)$ & $3(9.68)$ \\
\hline \multicolumn{4}{|l|}{ Number of years living in Mayoyao } \\
\hline$>10$ & - & $1(5.88)$ & $1(3.23)$ \\
\hline 11 to 20 & $3(21.43)$ & $1(5.88)$ & $4(12.90)$ \\
\hline 21 to 30 & $4(28.57)$ & $2(11.76)$ & $6(19.35)$ \\
\hline 31 to 40 & $3(21.43)$ & $4(23.53)$ & $7(22.58)$ \\
\hline 41 to 50 & $1(7.14)$ & $4(23.53)$ & $5(16.13)$ \\
\hline 51 to 60 & $2(14.29)$ & $3(17.65)$ & $5(16.13)$ \\
\hline$>61$ & $1(7.14)$ & $2(11.76)$ & $3(9.68)$ \\
\hline
\end{tabular}

\section{Determinants of socio-ecological resilience}

Thematic analysis identified five major themes namely: 1) farming practice, 2) cultural tradition, 3) social network, 4) financial capital and 5) natural resources. Themes generated were categorized into two dimensions of SEPL (Sociocultural and Ecological). Socio-cultural comprised of farming practice, cultural tradition, social network and financial 
capital while ecological dimension includes natural resources (Table 2). Each theme was provided with the indicators (Table 2, column 3). These indicators are the resilience building strategies of the local people of Chaya.

Table 2. Determinants of Socio-Ecological Resilience of Chaya Socio-Ecological Production Landscape.

\begin{tabular}{|c|c|c|}
\hline Resilience Dimension & Themes & Indicators \\
\hline \multirow[t]{12}{*}{ Socio-cultural } & \multirow[t]{6}{*}{ Farming practice } & 1. Preservation of stone walls \\
\hline & & 2. Preference for subsistence farming \\
\hline & & 3. Practice of traditional farm labor (ubfu/me-ebto'/changa) \\
\hline & & 4. Maintaining woodlot (pinuchu) \\
\hline & & 5. Agricultural biodiversification \\
\hline & & 6. Preference for organic farming \\
\hline & \multirow[t]{3}{*}{ Cultural tradition } & 1. Continuous practice of traditional land inheritance system (pfano) \\
\hline & & 2. Transmission of indigenous knowledge and practices \\
\hline & & 3. Performance of rituals \\
\hline & \multirow[t]{2}{*}{ Social network } & 1. Existence of institutions aiding the community \\
\hline & & 2. Access to information related to farming \\
\hline & Financial capital & 1. Household income \\
\hline \multirow[t]{2}{*}{ Ecological } & \multirow[t]{2}{*}{ Natural resources } & 1. Diversity in tree species \\
\hline & & 2. Availability of natural water source (e.g. spring or "ofhob" river "gwang-gwang") \\
\hline
\end{tabular}

\section{Farming practices}

The farming practice is one of the major themes which emerged from the different sectors. Farming practices mean in this study are the practices related to rice production. All participants from all sectors claimed that it is important for them to continue the traditional farming practices. These are preservation of stonewalls, subsistence farming, traditional farm labor (ubfu/me-ebto'/changa), maintaining woodlot or "pinuchu", agricultural biodiversification and preference for organic farming.

\section{Preservation of stone walls}

Majority of the rice paddies are stone walled (Fig. 4). These stone walls are manually arranged according to size and soil acts as binder. In Chaya, majority of the visible stonewalls are still original. The sturdy stone walled terraces have made it possible for the terraces to last for a long time. One barangay official noted that Chaya has the most intact stonewalls among the barangays in Mayoyao. 


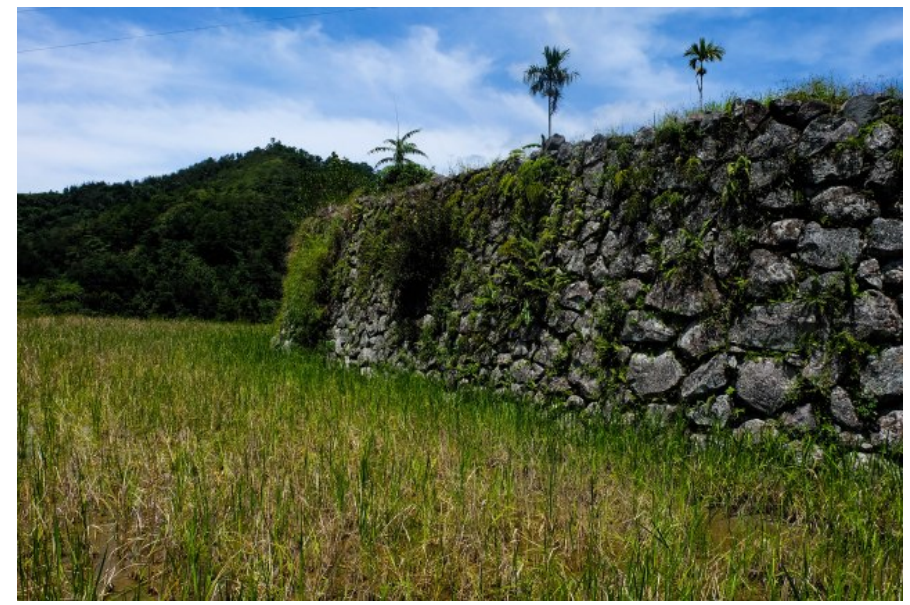

Fig 4. The intact and original stonewalls of Chaya Rice Terraces.

Farmers and barangay officials mentioned that it is their culture to always maintain the stone walls and whenever there are damages, they immediately repair it if they have the means to restore it. As farmer mentioned, "Tapengon cha ta epapfang-ngad cha aychin ena'at na ta mahalimunan" (The farmers repair the stone walls by doing riprap, so it is always maintained). They always hope that the stonewalls will still remain because it serves as the foundation of the paddies. Stonewalls are very significant for them and considered the rigid structure of the SEPL. In fact, they compared themselves as stonewalls that are never been broken.

\section{Preference for subsistence farming}

All the participants never sell their harvest but use it solely for home consumption. They prefer their own produce rather than commercial rice. For them, the local variety of rice is safer because all the inputs used are organic (Fig.5). For all the participants, reliance on their own produce helps them to be more food sufficient. When rice is sufficient it means there is buffer until the next cropping. Participants from Educator sector expressed that they are sufficient in rice. As one preschool teacher mentioned, "Maid poblema hi anun,uray un it-it-tang muti achi cha mapohan ja mangan cha hi mamitlo hi ahay arkhaw." (There is no problem in the food, at least food is always around, and we eat three times a day). 


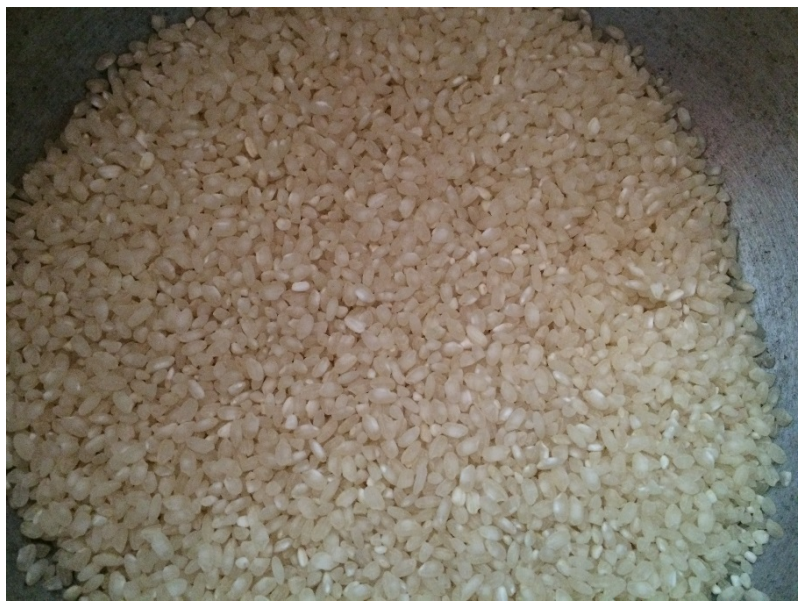

Fig 5. The traditional organic heirloom rice preferred by locals of Chaya.

\section{Practice of traditional farm labor (ubfu/me-ebto'/changa)}

A strong community relationship still exists in Chaya. As one farmer noted, "The number one thing that I observed here is we have a strong community relationship." Most of the participants from all sectors claimed that whenever there is a need to repair some broken irrigation canals or terraces, the spirit of community cooperation (pacham) is always at hand. Farm labor in the form of ubfu (exchange of free labor), me-ebto' (participation in the harvest with share or 1 or 2 bundle of rice) and changa (render free service with free meal) and is also being practiced in the locality until today. Farmer participants mentioned that this kind of system helps them to become more self-organized and not too become dependent to the government.

\section{Maintaining woodlot or "pinuchu"}

Pinuchu is recognized by all sectors as important component of CSEPL (Fig. 6). Pinuchu is a system which regulates the maintenance and the communal use of the land. Participants follow customary laws such as prohibiting burning during summer to avoid massive wild fire and no cutting of water-producing trees (e.g. Ficus nota "lapfoy"). One farmer expressed, "Unmi lang khun unuchon chin khun cha aton chin nahop amat ayni aton an manalimon ayni arpugwan tay chanum." (We are just following what our forefather were doing before, like the preservation of watershed). When people do slash and burn, they replanted the vacated space immediately. They do not simply cut trees. They also follow ordinances when it comes to the protection of the pinuchu. One of the ordinances being strictly implemented is "Ordinance No. 8-an ordinance prohibiting the cutting of trees from the pinuchu duly assessed or declared forest land of somebody within the territory of Brgy. Chaya." The cutting of trees without the consent/permission of the declarant/owner of the pinuchu is strictly prohibited. Any person violating this ordinance will be penalized at PhP 50,000 per offense and other legal charges/penalty depending on the recommendation of the offended party. The fines that will be collected will go directly to the trust fund of the barangay and will be used to purchase seedlings for reforestation purposes. As the rice terraces are dependent on forest for its continuous irrigation, following ordinance like this is essential for the protection of watershed. This is the main reason why the watershed has been preserved. 


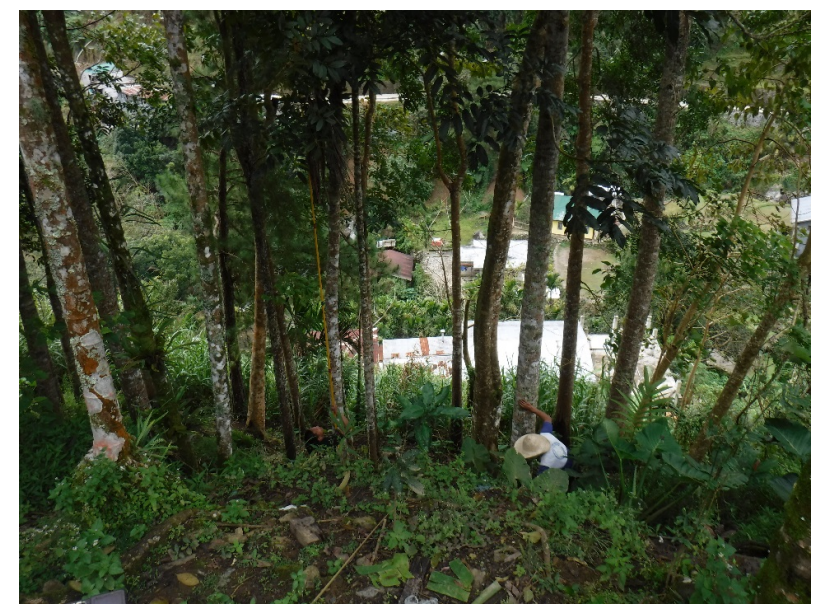

Fig 6. A woodlot (pinuchu) located in Sitio Lengleng, Chaya, Mayoyao, Ifugao

\section{Agricultural biodiversification}

All participants highlighted the important role of genetic diversity. As they said, tinawon is the common variety of rice that is being planted in Mayoyao but because it is now easily attacked by pest and diseases, farmers find other resistant varieties. Most of these, are modern varieties that are high yielding and resistant to pest and diseases. But despite planting different variety, they still maintain the traditional rice variety (e.g tinogon, fa'lar an, natalang-tang). Tinawon is integrated with modern varieties to guarantee that there will be sure production.

Aside from rice, there are different sources of food that can be found in the rice field. According to one member of people's organization, there is no problem with hunger and even during calamity, participants can still survive because there are different sources of locally available food. Vegetables are planted in the rice field and also, they integrate fish in the paddies (Fig.7). Some of the crops and vegetables include Colocasia esculenta (taro), Ipomoea batatas (camote), Nasturtium officinale (water cress), Brassica rapa (pechay) and Cucurbita maxima (squash). Barangay officials said that during El Niño season, these served as alternative to rice during long period of drought. The practice of crop diversification and integration of fish and livestock in the field is one of their resilience building strategies. 


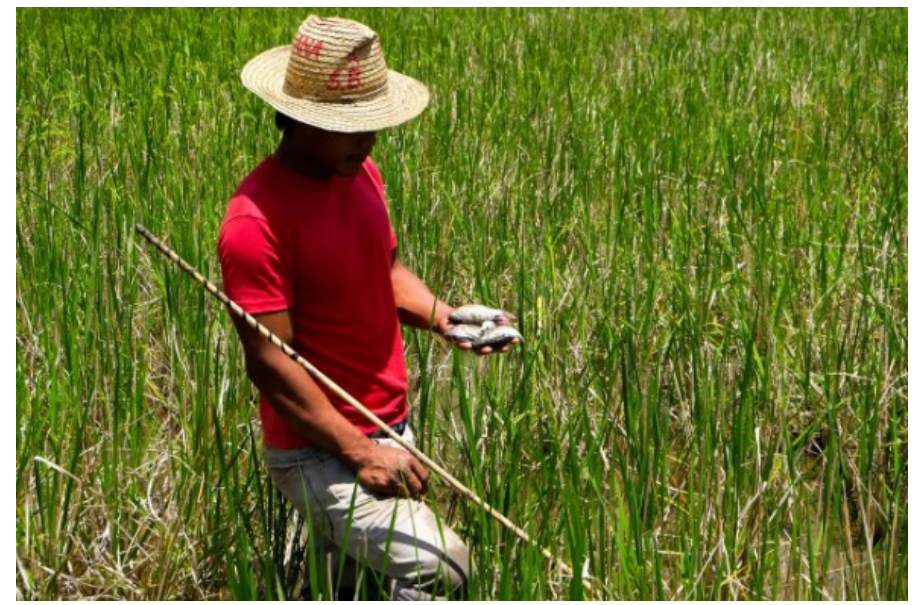

Fig 7. The integration of fish in the rice field of Chaya Rice Terraces.

\section{Preference for organic farming}

Participants from all sectors put emphasis on the importance of using organic fertilizers and pesticides in the field. Majority of them use green manure (e.g. rice stalk, weeds and sunflowers) and animal manure as fertilizers for the soil. These are applied during land preparation. They believed that inorganic fertilizers and pesticides will create imbalance in their environment. As one farmer expressed, "Achi ami khun mun-usar hana pfortaliser an manginan ti unchain ja pa'iyona hato pajaw." (We do not use commercial fertilizer because it can harm the environment). Another participant from the organization refused to use pesticide for it makes the soil binder in the stone walls soft causing it to collapse. Therefore, the practice of organic farming is seen beneficial in maintaining the integrity of the rice field. Participants from all sectors also do this to ensure that what they eat is free from chemicals which is safe for consumption. However, consequence of organic farming was mentioned by farmer sector. According to them, there is now a decrease in crop yield because the organic fertilizers they are using are not enough to sustain the soil fertility.

Despite valuing organic farming, participants from educator group mentioned that there were cases wherein farmers were using synthetic chemicals to control pest (e.g. giant earthworms and golden apple snail (GAS). Farmers were applying salt, lime, used engine oil, chlorine and Clorox in the paddies to control giant earthworms. For the control of GAS some were using SureKill ${ }^{\circledR} 70$ WP. This practice was adapted by farmers as it was seen effective in Isabela Province.

\section{Cultural traditions}

The continued practice of traditions and practices is another theme that emerged from the entire sectors. They believed that their traditions are big contributors for their resilience. Cultural tradition in this study means the traditions that are unique in Ifugao. The following variables indicate that traditions are still being practiced in the community, namely: traditional land inheritance system (pfano), transmission of indigenous knowledge and practices and performance of rituals. 


\section{Continuous practice of traditional land inheritance system (pfano)}

The pfano is a land inheritance system wherein most of the property is transferred to the eldest child to avoid rice field fragmentation. This practice ensures the continuity of rice cultivation. All participants have high respect to the land. For them it is a treasure that should be handed down from generation to generation. The land has a sentimental value for it was handed to them by their ancestors. One barangay official expressed, "Penhod un ipa-annila aycha ni empfa-pfalay u an achi ta mon-ngina hi pajaw." (I want to tell my children that they should not sell the rice fields). Selling of land without the consent of the immediate family members or clan is strictly forbidden.

\section{Transmission of indigenous knowledge and practices}

Majority of the participants recognized the importance of transmission of indigenous knowledge and practices to the young generation. One of the required skills that should be learned is the process of stone walling. In the presence of disturbance such as giant earthworms and landslide, all participants believed that it is necessary for the community to have a pool of individuals who are trained in stone walling. They also want their children to become aware of their culture since children nowadays are less interested on rice culture because of the influence of modernization. They want their children to know not just only the process of stone walling but also how the rice terraces are connected to their rich cultural heritage. Older participants from all sectors are also trying to pass the local knowledge of crop, seeds, soil and water management and traditional farming to their children. Participants from the educators group mentioned that they have been telling the importance of the rice terraces whenever topic about nature is being discussed in the classroom. Another important strategy to relive the revered cultural customs of their ancestors, is the conduct of the annual celebration called Igkhumtad ad Majawja. The main events of the festival include the rice rituals, ethnic games, song contests, tajaw or native dance contest per district, search for Ms. Igkhumtad, and the parade of barangay residents wearing their native attire.

Participants from farmer sector mentioned that bringing the young ones to the field and transferring traditional knowledge is vital to increase awareness about their culture. Participants from youth sector confirmed that the continuous interaction with the landscape could develop some affective attachment to the rice culture. They claimed that going in the field with their parents is essential, so they can learn and appreciate rice farming.

\section{Performance of rituals}

To combat the impacts of disturbances such as pest, municipal official recognized rituals effective in pest control and should be revived. They said that pest problems before were eliminated by performing rituals. The other rituals that are still being practiced in the community are the: 1) Honga- a ritual performed to drive away evil spirits before planting and 2) Khipid- the practice of sexual abstinence before planting. Barangay officials highly believed that rituals are still effective. However, participants expressed that there is now a declining number of traditional ritual performers because of the introduction of Christianity.

\section{Social network}

Social networks which refer to the groups, organizations or government bodies are seen important for the resilience of CSEPL. For all groups, the existence of institutions aiding the community as well as access to information related to farming allow the individuals to cope with the new challenges they are facing. 


\section{Existence of institutions aiding the community}

All participants considered institutional support as significant. The Ifugao Cultural Heritage Office (ICHO) provides resources that are needed for the restoration of damaged terraces. Participants claimed that ICHO had helped them a lot in financial aspect. ICHO also provides training on stone walling that capacitates young generation. Meanwhile, the Municipal Social Welfare Development (MSWD) provides relief goods to the families affected by natural calamities. The Municipal Agriculture office (MAO) provides extension support and agricultural inputs (e.g. seeds, fingerlings, organic fertilizer) to farmers. On the other hand, the farmers irrigators association and the barangay officials are the key players in initiating rehabilitation and repair of irrigation canals and stonewalls after disasters. These two are also disseminating agricultural information to the farmers.

\section{Access to information related to farming}

Access to resources whether it is new information or technology is essential for the people. All group participants admitted that the traditional way of farming at present is not that enough in battling with impacts of disturbances they are facing. All group participants were receptive to new suggestions. As one member of organization expressed, "If possible, we hope you can help us how to eradicate the earthworms." Participants are being open-minded and very willing to learn and innovate. At present, majority of the participants are getting information from fellow farmers and agricultural technologist. Television and radio are also mentioned as sources of information. Information on modern technology is also important according to the farmers. Farmer sector claimed that they need to try some modern equipment to lessen the intensive labor requirements in the field. They believed that with existence of technology, there will be less chance of abandoning the paddies for modern technology makes farming easy.

\section{Financial capital}

All participants recognized financial capital as determinant of resilience. People need to have stable income to support their living and to maintain the rice terraces. The rice terraces are source of livelihood but only the vegetables planted in the field are being sold since rice is for subsistence. Income mostly comes from off-farm sources including daily wage laborers, driving, being government employees, carpentry, business, masonry, overseas work and tourism.

\section{Household income}

Based on the CMPIP (2011), the average monthly household income in Barangay Chaya is below PhP 20,000 which is below compared to the PhP 22,000 average household monthly income in the Philippines (PSA, 2015). According to the participants, individual with high income can do much better than the family with low income. This is observed by all farmer and organization participants in terms of restoring stone walls or rice field maintenance. Farmer sector acknowledged the importance of income to cope with challenges in the terraces. They said that this is highly needed for repairing damaged stone walls. In addition, income is needed for providing basic needs such as food, education, medicine and clothing. 


\section{Natural resources}

Chaya's intact forest is one of the factors that builds and sustains resilience. In addition, natural spring acts as buffer in case of drought or El Niño incidence. For them, the rice terraces would not exist without the following, namely: trees species diversity and availability of natural water source (e.g. spring "ofhob", river "gwang-gwang").

Trees species diversity

All participants mentioned that Chaya has the most intact forest among the villages in Mayoyao. Trees are playing important role in the resilience of CSEPL as it generates multiple ecosystem services. All participants of focus group discussions claimed that the forest acts as watershed ensuring that there is all year-round supply of water for the rice field. Different trees species have different roles. Some trees are used as timber. Other tree species are being used as organic fertilizer and natural medicine. In Chaya, most of the houses are made of wood and the families are getting timber from their pinuchu. According to the educators, trees also protect them from strong typhoon and provide aesthetics.

Availability of natural water source (e.g. spring "ofhob", river "gwang-gwang")

Rice paddies need to have adequate supply of water to maintain flooded conditions of the rice field. Maintaining paddies in a flooded condition reduce possible soil erosion and cracks. The Liwo River serves as source of water for the whole Chaya community and the six nearby barangays. They said that their ancestors constructed a diversion dam for the community to have irrigation for the rice terraces. The water supply is always available, but water shortage happens during summer and El Niño days. Participants mentioned that whenever there are water shortages, only those who have direct access to water are the ones who have the chance to plant rice. In addition, paddies with natural spring (ofhob) are also advantageous. During drought period, the people take advantage of the ofhob and use it for irrigation. The farmers who have ofhob will share it to the neighboring field, so they can still plant rice. During the last El Niño, $80 \%$ of the farmers were not affected. The secret according to them is their "ofhob".

\section{The challenges in CSEPL}

The CSEPL is faced with different challenges and according to the people these can affect their current resilience. These are, 1) influx of the invasive giant earthworms, 2) declining interest of young generation towards farming and 3) climaterelated disturbances. Among the challenges mentioned, invasive species, particularly the giant earthworm is the main problem followed by climate-related disturbances and lastly, young generation problems. Table 3 illustrates the challenges identified by the locals during FGDs. 
Table 3. The challenges in the CSEPL identified by the indigenous people of Chaya.

\begin{tabular}{|l|l|}
\hline \multicolumn{1}{|c|}{ Challenges } & \multicolumn{1}{c|}{ Illustrative data extracts } \\
\hline $\begin{array}{l}\text { Influx of the invasive giant } \\
\text { earthworms }\end{array}$ & "Hini olang an hinuy hini mun-nawd an napukhit an mama'-I hi pajaw." (That earthworm is the main evil.) \\
\hline $\begin{array}{l}\text { Declining interest of young } \\
\text { generation towards farming }\end{array}$ & $\begin{array}{l}\text { "Mahoholetan ami an tomolong ja mamenghan ja mahiw ami hato punbuyan ja ay-ayam." (We are getting lazy, and } \\
\text { gadgets hinder us from helping.) }\end{array}$ \\
\hline $\begin{array}{l}\text { Climate-related disturbances } \\
\text {-Unpredictable weather pattern }\end{array}$ & $\begin{array}{l}\text { "Idi ja ma-a'-annila mi nu tijarkhaw muti tan ad ugwani ja numbaliw" (Before we can determine if it is summer season but } \\
\text { now it's different.) }\end{array}$ \\
\hline -Pest and diseases & $\begin{array}{l}\text { "Hini pfu-aw ja pfumutay nu tijarkhaw an maid uchan." (Pfuaw occurs only when there is no rain especially when there is } \\
\text { long period of drought.) }\end{array}$ \\
\hline $\begin{array}{l}\text {-Landslide due to natural } \\
\text { calamities }\end{array}$ & $\begin{array}{l}\text { "...cho'cho'or chi kochay nu panag-uuchan karkaro nu mapfi-ah ja achi na ita'ta'chug..." (Landslide occurs during heavy } \\
\text { rains and if it is continuous, there is a higher tendency that the stone wall will be eroded.) }\end{array}$ \\
\hline
\end{tabular}

\section{Influx of the invasive giant earthworms}

All the participants in the focus groups labeled giant earthworm as a major cause in physical degradation of Chaya rice terraces. It damages the paddies in this manner; the earthworm bore deep within the terraces stones, penetrating on the soil binder and eventually creating hole in the walls leading to water seepage. This is the beginning of the collapse of the stone walls and erosion of the surrounding soil material. Aside from destroying the terraced paddies, it has an impact to crop production. By creating water seepage, the field becomes dry which causes crop damage and reduction in yield. Farmers tried using the bark of Harpullia arborea (Blanco) Radik. locally known as tupfa to control the giant earthworm but tupfa according to them was not that effective.

Giant earthworms have become a big problem for most of the participants and with this, the farmers wanted to use cement as binding material for their stone wall so that the giant earthworm could not penetrate and burrow. They believe that the use of cement will make the stone walls last longer. However, using cement as binding material requires bigger funding especially for massive restoration. In addition, the municipal officials mentioned that UNESCO has restricted the use of cement as these can dilute the authenticity of the terrace. With the many prescriptions of UNESO, some of the officials mentioned that it is alright for them to be delisted in the UNESCO. They believed that this organization just prescribed so many things but does not really help in the restoration or maintenance of the rice terraces.

\section{Declining interest of young generation towards farming}

The participants from all sectors agreed that modernization and education are influencing the world view of the young generation when it comes to farming. Participants from the barangay council agreed that only five percent of the youth are helping in the fieldwork while the remaining $95 \%$ have other priorities. As barangay officials expressed, "They have cellphones." "They are students and refuse to soak in the mud." "They have computers and there are televisions." Farmers, barangay and municipal officials pointed out that the rise of social networking site like Facebook has drastically changed the mindset of the young people. Aside from these, the introduction of rice mill in the locality became a barrier for learning the traditional way of pounding rice. Since rice mill is present, there is no reason for them to know the traditional practices. These claims were confirmed by the youth participants. When asked why they are no longer helping 
in the field, the youth expressed their interest on gadgets over farming. The youth participants mentioned that they are students and their top priority is to study. They also mentioned that they could not help in the field because their parents assigned to them different tasks such as taking care of their younger siblings or doing household chores during weekends. Additionally, the young generation preferred to hang out with friends every weekend or during their free time. Each of them was also asked on the course they wanted to take in tertiary school and most of them selected the field of Engineering, Health Sciences and Education. Agriculture or Forestry courses were never mentioned. This showed that the trend is towards industrial work and not on farming.

\section{Climate-related disturbances}

All groups observed that there were changes in the climate. They said that previously, the coolest month is December but currently moved to January and February. Even on summer season, they are now experiencing rain with thunderstorm. Climate is very unpredictable as one municipal official noted, "Before we can determine if it is summer season but now it's different." Other changes observed are long period of drought and warming temperature. According to them, too cold temperature resulted in stunted growth of rice while long period of drought exacerbates pest and disease problem. Hydrellia philippina Ferino or locally known as pfuaw is believed to occur when there is a long period of drought or warming temperature. According to the participants, the insect attacks during vegetative stage. The infested plants produced unfilled grains (chupar) leading to reduction of their harvest. On the other hand, natural disasters such as strong typhoons and heavy rains cause landslide in the rice terraces which leads to the destruction of stonewalls (Fig.8). When the extent of damage is too big, farmers do not restore the stone walls because it would take so much labor cost for those specialized in stonewalling. This is the reason why many farmers in Chaya abandoned their rice field.

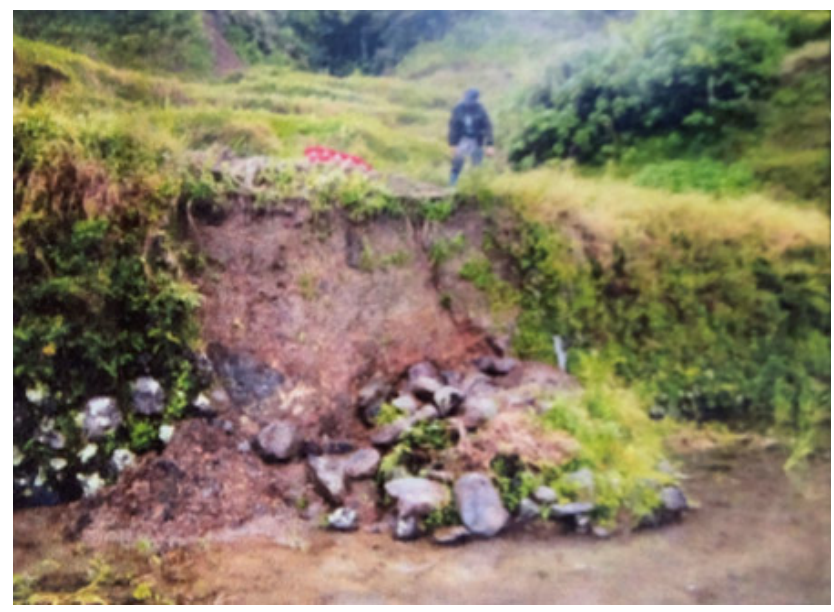

Fig 8. Landslide damages caused by Typhoon Koppu (Source: Chaya Typhoon Lando Damages Report, 2015). 


\section{Discussion}

Five major themes were elicited for this study namely: 1) farming practice, 2) cultural tradition, 3) social network, 4) financial capital and 5) natural resources. Each theme has its corresponding indicators (Table 2) which served as Chaya's resilience building strategies. However, with the given strategies comes three challenges which are believed to have great impact on the current level of their resilience, namely: 1) influx of the invasive giant earthworms, 2) declining interest of young generation towards farming and 3) climate-related disturbances.

As expected, some of the determinants of resilience (Table 2, column 3) agree with the indicators used by Castonguay et al. (2016) and Castonguay (2014) in assessing the resilience of Banaue rice terraces. These are pinuchu system (Fig. 6), traditional farm labor or bayanihan spirit, observance of rights (pfano), performance of rituals and agro biodiversification. This implies that regardless of location of the terraces whether remote or not, these determinants of resilience are unique for Ifugao and can be considered as salient factors contributing to resilience. Other indicators are also consistent with the socio-ecological resilience indicators proposed by Mijatović et al. (2013) and van Oudenhoven et al. (2011). These are transmittance of traditional knowledge and practices, social networks and agro biodiversification. The concept of biodiversity, cultural traditions such as transmission of traditional knowledge are also similar with the indicators of resilience used in assessing the SEPL of Lefke Region in North Cyprus (Ciftcioglu, 2017). Traditional culture is also an indicator of resilience and considered as an important power for maintaining Hani terraces SEPL (Zhang et al., 2017). On the other hand, overall income, information sources, and preference for organic farming were also identified as important indicators of social-ecological resilience of cocoa farming systems SEPL in Alto Beni, Bolivia (Jacobi et al., 2015). Meanwhile, dependence on natural resources is consistent with the indicators of SEPL (Bergamini et al., 2013). The importance of forest has been recognized by the Hani people because it plays an important role in the maintenance of traditional Hani culture and community bonds. It also helps in educating the younger generation about forest custodianship (Gu et al., 2012). It can be concluded that the above-mentioned indicators are significantly important in strengthening and building the resilience of a socio-ecological production landscape and should be used for monitoring vulnerabilities in social-ecological systems.

When it comes to unique determinants for Chaya SEPL, the sturdy stone walled rice terraces (Fig. 4) and the natural spring "ofhob" stand out. However, with the influx of giant earthworm and climate-related disturbances such as strong typhoon, the stone walls and "ofhob" are seriously at risk. The giant earthworm has been documented since the early 1980's (Conklin, 1980) and yet until now there are still no available effective measures developed to control the giant earthworm (Ngidlo, 2013a; Castonguay et al., 2016). That is why farmers opted to use pesticides to eradicate this invasive species which is alarming since this practice contradicts their preference for organic farming. Another issue related to farming is the decline in agricultural productivity. Some farmers believed that organic fertilizer is now not enough to sustain the soil fertility leading to reduction in yield. Pest and diseases brought about by changing climate are also contributing to the losses. These are needed to be addressed immediately for it will have an impact on their food security. Improving organic farming techniques like what was done in the Andean traditional landscape, Potato Park in Peru can serve as model to address this issue (Asociacion ANDES and the Potato Park, 2015). 
With the existence of giant earthworm, the idea of using cement as binding material for the stone wall emerged. The local people wanted to take advantage of the modern technology, but they believe that UNESCO policy impede with their desired advancement. This created a dilemma on whether to follow the UNESCO policy to retain the prestige status or use cement as solution for the giant earthworm. Being inscribed in the UNESCO list is advantageous because it includes many benefits like economic benefits from tourism and creating partnerships between government, the private sector, and NGOs to achieve conservation goals. (LLP, 2007). However, as culture is evolving (Turner and Maryanski, 2008), UNESCO needs to revisit and upgrade their policies considering the situation of the 21 st century. The use of cement will make the walls stronger and last longer and this can be considered to reduce the negative impacts of the giant earthworm. Another option would be to determine the natural enemies of the giant earthworm. The native rodent species of Banaue, Ifugao, prey upon the giant earthworms which is also a serious pest to rice production in Banaue (Singleton et al., 2008). This can be considered for future research.

Pertaining to the stone wall preservation, another potential problem would be the declining interest of young generation towards farming. With disinterest follows erosion of knowledge, skills and practices (Soriano et al., 2017). In this case, the stone walling skill which is needed for preservation is in peril except if continued transmittance of knowledge and practices will be retained. This can be done in the form of the usual parent-children interaction in the field or integrating the indigenous knowledge and practices into the elementary and high school curricula in Ifugao (Calderon et al., 2008). With the youth preference of using gadgets, the social media can serve as a tool for transmittance of indigenous knowledge and practices. Social media is a powerful tool for awareness campaign and would successfully boost the spirit of the youth to participate even if they do not understand exactly what they are doing (Susilowati, 2014). The indigenous knowledge systems and practices according to Ngidlo (2011) are the primary bonds that sustains the resilient nature of traditional agricultural systems therefore transferring these to the young people is very important. Aside from transmittance of knowledge, other strategies to attract young people to farming is to uplift the image of farming. Many countries are providing incentives to attract youth to work in agriculture, particularly improved access to capital and land but this is not enough to ensure that they will not leave rural areas (Susilowati, 2014). There should be innovation such as combining tourism and farming. In addition, branding of local variety of rice is highly encourage for better market. In the case of Chaya, this innovation in farming plus the continuous pfano system would sustain the rice terraces.

For all the above scenario, a clear pattern is observable, all the determinants incorporate the idea of adaptation, learning and self-organization and the ability to persist the disturbances (Folke, 2006) which are the main components of resilience.

\section{Conclusions and Recommendations}

To date, limited information exists in the literature regarding the conceptualization of socio-ecological resilience of the rice terraces located in the remote areas of Luzon Island. This study offers to fill this gap. As the result of conducting this research, socio-ecological resilience of the Chaya Rice Terraces as a Socio-Ecological Production Landscape is conceptualized by the people as the ability of the traditional landscape to provide ecosystem services such as food, water, regulating functions and aesthetic. This answered the question "resilience of what". The "resilience to what" was 
answered in this study as the challenges being faced by the CSEPL and these are: 1) influx of the invasive giant earthworms, 2) declining interest of young generation towards farming and 3) climate-related disturbances. This study identified the determinants of resilience consisting of: 1) farming practice, 2) cultural tradition, 3) social network, 4) financial capital and 5) natural resources. With the abovementioned challenges, there is a need to conduct a resilience assessment and investigate these five resilience building strategies to identify vulnerabilities in the CSEPL. This is important so that action can be taken to create more sustainable future for people and the land. This study recommends policy makers in the global, national and local level to revisit or upgrade their policies about traditional landscape conservation in response to the evolving culture.

\section{Statement of authorship}

This study was part of the thesis of the first author for Master of Science in Environmental Science at the University of the Philippines Los Baños. The manuscript was prepared by the first author with significant contributions from the second author.

\section{Acknowledgements}

The corresponding author would like to acknowledge the Ifugao Satoyama Meister Training Program (ISMTP) for adopting this research in the program, the Department of Science and Technology Science (DOST) through the Science Educational Institute (SEI) under the accelerated S \& T Human Resource Development (ASTHRDP) and the Southeast Asian Regional Center for Graduate Study and Research in Agriculture (SEARCA) for funding this research, the University of the Philippines Los Baños for the references and facilities provided. The authors would like to express their deepest gratitude to the local government of Mayoyao, Ifugao and the local people of Barangay Chaya for their active participation in this study.

\section{References}

Andes, A. the Potato Park., 2015. Biocultural Heritage Innovations in the Potato Park. SIFOR Qualitative baseline study, Peru.

Araral, E., 2013. What makes socio-ecological systems robust? An institutional analysis of the 2,000-year-old Ifugao society. Human Ecology, 41(6), 859-870.

Bergamini, N., Blasiak, R., Eyzaguirre, P., Ichikawa, K., Mijatovic, D., Nakao, F., Subramanian, S. M., 2013. Indicators of resilience in socioecological production landscapes (SEPLs), UNU-IAS policy report. United Nations University Institute of Advanced Studies, Yokohama.

Berkes, F., J. Colding, C., Folke, editors., 2003. Navigating social-ecological systems: building resilience for complexity and change. Cambridge University Press, Cambridge, UK. 
Braun, V., Clarke, V., 2006. Using thematic analysis in psychology. Qualitative research in psychology, 3(2), 77-101.

Calderon, M. M., Dizon, J. T., Sajise, A. J. U., Andrada, R. T., Bantayan, N. C., Salvador, M. G., 2008. Towards the development of a sustainable financing mechanism for the conservation of the Ifugao Rice Terraces in the Philippines. EEPSEA, IDRC Regional Office for Southeast and East Asia, Singapore, SG.

Carpenter, S., Walker, B., Anderies, J. M., Abel, N., 2001. From metaphor to measurement: resilience of what to what? Ecosystems, 4(8), 765781.

Castonguay, A., Burkhard, B., Müller, F., Horgan, F., Settele, J., 2016. Resilience and adaptability of rice terrace social-ecological systems: a case study of a local community's perception in Banaue, Philippines. Ecology and Society, 21(2).

Castonguay, A., 2014. Assessment of resilience and adaptability of social-ecological systems: a case study of the Banaue rice terraces. University of Kiel: Kiel, Germany.

Chaya Mayoyao Project Investment Plan., 2011

Chaya Typhoon Lando Damages Report., 2015

Ciftcioglu, G. C., 2017. Assessment of the resilience of socio-ecological production landscapes and seascapes: A case study from Lefke Region of North Cyprus. Ecological indicators, 73, 128-138.

Conklin, H. C., 1980. Ethnographic atlas of Ifugao; a study of environment, culture, and society in northern Luzon. Yale University Press, New Haven, Connecticut, USA.

Di Falco, S., Chavas, J. P., 2008. Rainfall shocks, resilience, and the effects of crop biodiversity on agroecosystem productivity. Land Economics, 84(1), 83-96.

Fereday, J., Muir-Cochrane, E., 2006. Demonstrating rigor using thematic analysis: A hybrid approach of inductive and deductive coding and theme development. International journal of qualitative methods, 5(1), 80-92.

Folke, C., 2006. Resilience: The emergence of a perspective for social-ecological systems analyses. Global environmental change, 16(3), 253267.

Gu, H., Jiao, Y., Liang, L., 2012. Strengthening the socio-ecological resilience of forest-dependent communities: The case of the Hani Rice Terraces in Yunnan, China. Forest Policy and Economics, 22, 53-59.

Jacobi, J., Schneider, M., Pillco Mariscal, M., Huber, S., Weidmann, S., Bottazzi, P., Rist, S., 2015. Farm resilience in organic and nonorganic cocoa farming systems in Alto Beni, Bolivia. Agroecology and Sustainable Food Systems, 39(7), 798-823.

Khalili, S., Harre, M., Morley, P., 2015. A temporal framework of social resilience indicators of communities to flood, case studies: Wagga wagga and Kempsey, NSW, Australia. International Journal of Disaster Risk Reduction, 13, 248-254.

LLP, P., 2007. The Costs and Benefits of UK World Heritage Site Status. A literature review for the Department for Culture, Media and Sport.

Mijatović, D., Van Oudenhoven, F., Eyzaguirre, P., Hodgkin, T., 2013. The role of agricultural biodiversity in strengthening resilience to climate change: towards an analytical framework. International journal of agricultural sustainability, 11(2), 95-107.

Ngidlo, R. T., 2013a. Assessment of Climate Change Impacts, Vulnerabilities and Adaptation Strategies in the Traditional Rice Terraces of the Cordillera Region, Northern Philippines. Asian Journal of Science and Technology, 4(11), 180-186.

Ngidlo, R. T., 2013b. The Rice Terraces in Ifugao Province, Northern Philippines: Current Scenario, Gaps and Future Directions. Global Journal of Biology, Agriculture and Health Sciences. Global Institute for Research and Education, 2(4), 151-154.

Ngidlo, R. T., 2011. Drivers of change, threats and barriers to the conservation of biodiversity in traditional agricultural systems. Journal of Agricultural Science and Technology, 1(5), 675-684.

National Statistics Office (NSO), Census of Population, 2010 
Ryan, G. W., Bernard, H. R., 2003. Techniques to identify themes. Field methods, 15(1), 85-109.

Save the Ifugao Terraces Movement (SITMo). Impact: The Effects of Tourism on Culture and the Environment in Asia and the Pacific: Sustainable Tourism and the Preservation of the World Heritage Site of the Ifugao Rice Terraces, Philippines. UNESCO Bangkok, Asia and Pacific Regional Bureaau for Education, 2008.

Schoon, M. L., Cox, M. E., 2012. Understanding disturbances and responses in social-ecological systems. Society \& Natural Resources, 25(2), 141-155.

Singleton, G. R., Joshi, R. C., Sebastian, L. S., 2008. Philippine rats: ecology and management.

Soriano, M. A., Diwa, J., Herath, S., 2017. Local perceptions of climate change and adaptation needs in the Ifugao Rice Terraces (Northern Philippines). Journal of Mountain Science, 14(8), 1455-1472.

Southwick, S. M., Bonanno, G. A., Masten, A. S., Panter-Brick, C., Yehuda, R., 2014. Resilience definitions, theory, and challenges: interdisciplinary perspectives. European Journal of Psychotraumatology, 5.

Susilowati, S. H., 2014. Attracting the Young Generation to Engage in Agriculture. Enhanced Entry of Young Generation into Farming.

Thomas, D. R., 2006. A general inductive approach for analyzing qualitative evaluation data. American journal of evaluation, 27(2), 237-246.

Turner, J. H., Maryanski, A., 2008. Explaining Socio-Cultural Evolution. The Limitations of Evolutionary Theory from Biology. Sociologica, 2(3), 00.

UNU-IAS, Bioversity International, IGES., UNDP., 2014 Toolkit for the Indicators of Resilience in Socio-ecological Production Landscapes and Seascapes (SEPL).

van Oudenhoven, F. J., Mijatović, D., Eyzaguirre, P. B., 2011. Social-ecological indicators of resilience in agrarian and natural landscapes. Management of Environmental Quality: An International Journal, 22(2), 154-173.

Zhang, Y., Min, Q., Zhang, C., He, L., Zhang, S., Yang, L., ... Xiong, Y. 2017. Traditional culture as an important power for maintaining agricultural landscapes in cultural heritage sites: A case study of the Hani terraces. Journal of Cultural Heritage, 25, 170-179 